\title{
Combination of Problem Based-Learning and Cooperative Learning: Efforts to Boost Students' Competence and Motivation in Learning at IGL Class English Department Universitas Andalas
}

\author{
Ike Revita ${ }^{1}$, Dhiant Asri ${ }^{2}$, Farah Anindya Zalfikhe ${ }^{3}$ \\ $\left\{\right.$ ikerevita@hum.unand.ac.id ${ }^{1}$,dhiant_asri@yahoo.co.id ${ }^{2}$, anindyazalfikhe@gmail.com ${ }^{3}$ \} \\ ${ }^{1,2,3}$ English Department, Faculty of Humanities, Universitas Andalas
}

\begin{abstract}
Learning Introduction to General Linguistics for English Department students is challenging because it is offered for those who are in the second semester. The topics cover the basic concepts related to Linguistics. Many students get failed in this course. This article is aimed at describing the combination of two of the method in students centered learning, problem-based and cooperative learning, to boost the motivation and competence of students in learning Introduction to General Linguistics for English. The research is conducted in the class provided for those who retake the course for 2nd or 3rd time. The results show that this combination worked reasonably well. Almost all of the students got satisfaction with the process. Even they claimed that their understanding is much better.
\end{abstract}

Keywords: Cooperative learning, Introduction to General Linguistics for English, Problem based learning.

\section{Introduction}

Introduction to General Linguistics (abbreviated with IGL) is one of the compulsory subjects in the English Department. All students, whatever their concentration, both Linguistics and Literature, are required to take these three-credit courses. Introduction to General Linguistics is not a prerequisite subject because it is offered to those of the second semester (II). Every 1st-year students is allowed to take this course.

In IGL, students are introduced to the basic concepts related to Linguistics. In other words, through IGL, students have been directed to know and understand things related to Linguistics but for beginner level. In this IGL, students are also led to having an awareness of language-related phenomena in their environment. Thus, at the end of the lecture, students are expected to be able to understand the fundamental aspects related to language while identifying the real language reality in the basic linguistic framework.

In IGL, students also learn how language is used in conjunction with other sciences. That linguistics does not stand alone but is also closely related to other fields of science. The discussion on this topic is designed in the $6^{\text {th }}$ meetings, namely Micro linguistics, Macro linguistics, and Applied Linguistics. Therefore, students increasingly understand that learning about language is not merely seeing pure linguistics but also in relation to other sciences.

IGL has already implemented student-centered learning. Students have been conditioned to be more active, in or outside the class, to identify and solve problems that are arranged in 
such away. Thus, students are relatively active in finding materials to enrich their understanding and knowledge. This method is carrying out an educational process characterized by long-life learning that masters hard skills, soft skills, and life skills. Such kind of learning is in line with the concept proposed by [1] that students have to make sense of information for information when they are to learn anything.

IGL class, students are directed to be active and independent. The students are no longer provided with the knowledge of 'catching up' and 'pulling up' which is only waiting for information from the lecturer. Instead, students are stimulated and motivated to actively find solutions to problems related to the IGL itself. Stimulation and motivation are expected to achieve maximum learning. One form of this stimulation and motivation is to provide home assignments for each topic every meeting [2]. The home assignment was in the way of a reading report written by each student and poured in a 1-2 page report, 1.5 spaces, with the format, Introduction; Content; References (minimum 3). This home assignment does not apply to groups who present their papers at the time. Independence and activeness of students are realized by designing learning in the form of seminars. Students are divided into small groups and are given one topic for each. Each group is responsible for explaining this material in accordance with the scheduled time. This material is also set forth in a simple paper with a predetermined format.

Such kind of method did not successfully work yet. Still, some students do not understand the topic discussed. Even when they were given a chance to provide a question, they did not provide any responses but busily find other activities, like looking for something at the reference.

This article then tries to elaborate on the phenomena of lack of motivation of students when they were learning IGL. The model of problem-based learning and cooperative learning were combined in this IGL class. The students were given some problems and they must find the solution in the group.

\section{Problem Based-Learning and Cooperative Learning}

Cooperative learning is one of the methods in the learning process under StudentCentered Learning (SCL). In cooperative learning, students interact with others to obtain and practice the elements of lecture material and find learning achievements [3].

Universitas Andalas, as one of the state universities in Indonesia, has implemented this SCL method in the teaching and learning process. In fact, the Rector of UniversitasAndalas has made regulation as outlined in Rector Regulation No. 3 of 2016 concerning the obligation to implement SCL.

English Department strongly supported this program by asking lecturers to use the methods in SCL to be used in lectures. IGL has implemented the SCL method but not yet comprehensive. In some topics and meetings, TCL is still used. This is partly triggered because the IGL talks more about the history of language development with experts.

The application of Teacher-Centered Learning in some meetings indirectly builds a less positive atmosphere towards students. This happens because the students become accustomed to being influenced by the lecturer's explanation. Even if they are asked to work in groups, only a certain number of students are active while others are more comfortable. As a result, the learning process does not run optimally.

For this reason, the SCL Cooperative Learning method was tested so that students could be actively involved and they were also able to apply concepts when given cases related to linguistic phenomena. In this Introduction to General class, students are then divided into 
several small groups, namely 3-4 people per group and then the Cooperative learning method is applied.

What they do in groups is what the lecturers designed. In the sense that they were deliberately given some cases related to the use of language. They were asked to find the solution for each case. Such kind of method is called problem-based learning. Students are encouraged to overcome and analyze the phenomena of how language is used in society. Problem-based learning is also inquiry-based so that the students may learn from the case they overcome $[3,4]$.

\section{Method of the Study}

Class Action Research (CAR) has contextual conditions, situations and situations in the classroom that are carried out to solve problems that occur in order to improve the quality of learning in the classroom [5] [6]. The CAR is generally carried out to solve problems that arise in the classroom so that the learning process can run effectively. In addition, CAR can foster a lecturer 's independent and critical attitude towards the situation in the class they are teaching.

[7] stated that CAR could improve the quality and learning practices implemented by lecturers in order to (a) Achieve learning objectives; (b) Improve and enhance learning performance performed by lecturers; and (c) Identifying, finding solutions, and addressing learning problems in class to create qualified learning.

The research was then conducted in the IGL class in 2019. There were around thirty-four students joining the class in which all of them retake the course for the 2 nd and the $3 \mathrm{rd}$. The course was deliberately created to accommodate those who failed in this course.

The data were taken during the process of learning from January until May 2019 by the observational method [7], with note-taking, interviewing, and giving questionnaires. The results of the analysis are descriptively and narratively done.

\section{Result and Discussion}

There are two team teachings in which each of these team teachings will be the tutors for each group of students. These group of students will be allowed to discuss through some stages a) identification of terms they are not yet familiar with, b) identification of problems; c) brainstorming; d) formulating learning objectives (guided by the existing syllabus); e) independent study; and f) they gather again to re-discuss the results of their respective understandings.

There are several sub-methods used in the process of combining problem-based learning and cooperative learning, as described below

a. Think-Pair-Share

Here students were given a topic or case related to the real language phenomenon. These students were asked to provide a quick response after being carried about 1-2 minutes to think. This response was then brought into their own groups for discussion. The results of this discussion were further developed in a larger group, combining two to three groups. In this way, students' abilities can be stimulated through a process of reflection and verbalization.

b. Three-step interview 
Three-step interviews were used as ice-breaking so that there is chemistry between students. Even though they are classmates because IGL is a subject that can also be taken from different batches. For this reason, three-step interviews were used so that each student can feel comfortable when discussing started with questions and answers done in paired. Then, each of them switched partners and asked the same points.

c. Numbered Heads Together

Students were divided into small groups, around 3-4. The lecturer gave factual questions to students. Students then discussed with their friends so that each group member understands the answer to the question. Then the discussion was carried out by randomly pointing students to answer the questions given. Students were relatively active because each of them has mastered the material well enough.

d. Three-minute Review

Students were given about 3-5 minutes to discuss and review what was discussed.

e. Partners

Classes were divided into two large groups, each of which was divided into small groups of 4 people. They were given two different subtopics as part of the main topic discussed in the meeting. Each group member then spread to find a partner from a different large group. After sharing the understanding they had, all group members returned to their groups and discussed the results of sharing with other partners. They were then asked to make some kind of review of the material, the process carried out, as well as the possibility of improving the learning process.

The combination of problem-based learning and cooperative is a kind of internal encouragement that the students are triggered and encouraged to have the spirit to continue to search and seek. So, the understanding of the students toward IGL is better. However, the process may be a bit bothered by external aspects that may discourage these students. For examples are the provision of facilities and infrastructure as well as the schedule.

This is one of the obstacles. The combination of problem-based learning and cooperative learning methods with various existing sub-methods was of great possibility to boost student motivation and competence. This can be seen from the interview and questionnaires given to them. In the last three years, student grades in IGL can be categorized quite well because the failure rate is very low. However, the number of maximum grades (A) is still limited because the most number is in the range $\mathrm{B}$ to $\mathrm{B}+$ (range values 70-74 and 75-79).

The implementation of problem-based learning combined with cooperative learning factually encourages students in terms of motivation and competence. This is shown by the response of the students about their understanding of the topics. Around $95 \%$ of students understand the concept and $85 \%$ of them are able to apply the concept to linguistic phenomena. Although in the beginning, students seemed to have difficulty in the process of adjustment, students were finally able to get through and get used to the patterns and methods applied.

\section{Conclusion}

The combination of problem-based learning and cooperative learning was basically be implemented as an effort to stimulate students to be actively involved. Previously, the course was considered boring because it covers various topics. The density of the material and the schedule that tends to be 'infertile' causes the motivation of students to be not so strong.

After this combination was applied, the changes begin coming up. The students seemed interested in learning. Even, they actively took part in every session and discussion. The 
evaluation was done through discussions conducted by students when they discuss it in groups. In addition, observations, open interviews, questionnaires, documentation, and oral quizzes were also to be conducted. The success of this combined method can be seen from the final mark gained by the students.

\section{Acknowledgments}

I would like to thank Rector of Universitas Andalas and LP3M to fund the research. Thank is also addressed to the students of IGL class in 2019. To the team, Ibu Dhiant Asri, M.Hum., thank you for the great teamwork and team teaching. Faran Anindya Zalfikhe, thank you for the help in analyzing the data.

\section{References}

[1] P. Ramsden, Learning to Teach in Higher Education. London: Routledge, (1992)

[2] I. Revita, "Problem Based Learning: Upaya Meningkatkan Kompetensi dan Motivasi Mahasiswa dalam Pembelajaran Mata Kuliah Pragmatics di Jurusan Sastra Inggris Fakultas Ilmu Budaya Unand," in SNPPT 4, (2017)

[3] A. Jaedun, Prinsip-prinsip Penelitian Tindakan. Makalah Pelatihan PTK Bagi Guru Di Propinsi DIY. Yogyakarta: Universitas Andalas, (2008)

[4] I. Revita, "Tindak Tutur Mahasiswa Kepada Dosen," in International Conference on Multidisciplined Linguistics, 2010, p. (2010)

[5] A. Jaedun, Prinsip-prinsip Penelitian Tindakan. Yogyakarta: UNY, (2008)

[6] Budiawan, "Pengaruh Sikap Bahasa dan Motivasi Belajar Bahasa terhadap Prestasi pada Mata Pelajaran Bahasa Indonesia dan Bahasa Inggris Siswa SMA se-Bandar Lampung Tesis Universitas Indonesia," p. 205, (2008)

[7] A. Kwan, Problem-based learning. The Routledge international handbook of higher education, 91-107. London: Routledge, (2009) 